\title{
Seven wastes elimination targeted by lean manufacturing case study "gaza strip manufacturing firms"
}

\author{
Khalil A. El-Namrouty, Mohammed S. AbuShaaban \\ Dep't of Economics and political Science, Al-Oma Univesity, Islamic University- Gaza, Palestinian National Authority \\ Email address: \\ knamroty@iugaza.edu.ps (K. A. El-Namrouty), abushaaban@hotmail.com (M. S. AbuShaaban)
}

To cite this article:

Khalil A. El-Namrouty, Mohammed S. AbuShaaban. Seven Wastes Elimination Targeted by Lean Manufacturing Case Study "Gaza Strip Manufacturing Firms", International Journal of Economics, Finance and Management Sciences. Vol. 1, No. 2, 2013, pp. 68-80.

doi: $10.11648 /$ j.ijefm. 20130102.12

\begin{abstract}
The research paper aims to investigate and analyze the current situation of wastes elimination of the manufacturing firms in Gaza Strip and its important role for reducing the production cost; in addition it aims to promote lean thinking through studying the seven wastes that are targeted by the lean manufacturing philosophy. Wastes Relations Matrix (WRM) was implemented to analyze the effect of each waste on the other six wastes. The main findings are that lean manufacturing (wastes elimination) affects positively on reducing the production cost for the manufacturing business in Gaza strip.
\end{abstract}

Keywords: Lean Manufacturing, Managers, Production Cost, Gaza Strip

\section{Introduction}

A new vocabulary has developed in the past decade that stems from the Toyota Production System. Lean manufacturing is a concept whereby all production employees work together to eliminate waste (Meyers and Stewart, 2002).

Manufacturers throughout industries are moving to a different system of production called Lean Manufacturing. It is not talking about adding some new techniques onto how to build products, but actually changing the way of thinking about manufacturing (Abdullah, 2003). The seven wastes that are targeted by the Lean Manufacturing Philosophy are: Overproduction, Inventory, Over-processing, Motion, Waiting, Defects, and Transportation (Poppendieck, 2002).

Palestinian companies that are seeking the ability of an effective competition in the local as well as the global marketplace should be in superiority of producing their products within the least possible costs to achieve excellence in price and quality. There are 33933 working establishments in Gaza Strip including 3529 manufacturing firms. In reality, the manufacturing activities in Gaza Strip represent $10.4 \%$ of the total economy in Gaza Strip (PCBS, 2008).
Table 1. No. of the Manufacturing Firms Operating in Gaza Strip and their Distribution by the Employment Group Size.

\begin{tabular}{llllllll}
\hline \multirow{2}{*}{$\begin{array}{l}\text { Economic } \\
\text { Activity }\end{array}$} & Total & \multicolumn{7}{c}{ The Employment Group Size } \\
\cline { 2 - 8 } & $\mathbf{1 - 4}$ & $\mathbf{5 - 9}$ & $\mathbf{1 0 - 1 9}$ & $\mathbf{2 0 - 4 9}$ & $\mathbf{5 0 - 9 9}$ & $\mathbf{1 0 0 +}$ \\
\hline Manufacturing 3529 & 2883 & 442 & 158 & 36 & 5 & 5 \\
\hline
\end{tabular}

"Source: PCBS, (2008). Population, Housing and Establishment Census (2007), The Economic Establishments, The Final Results, Ramallah-Palestine".

\section{History of Lean}

After World War II, Japanese manufacturers were faced with the dilemma of vast shortages of material, financial, and human resources. These conditions resulted in the birth of lean manufacturing concept. Toyota motor company, led by its president (Toyota), recognized that American automakers of the era were out-producing their Japanese counterparts; in the mid 1940's American companies were outperforming their Japanese counterparts by a factor of ten. In order to make a move toward improvement early, Japanese leaders, such as, Shigeo Shingo and Taiichi Ohno, devised a new, disciplined, process-oriented system, which is known today as "Toyota Production System" or "Lean Manufacturing" (Abdullah, 2003).

Taiichi Ohno, who was given the task of developing a system that would enhance productivity at Toyota, is generally considered to be the primary force behind its system. 
After some experimentation, the Toyota production system was developed and refined between 1945 and 1970, and is still growing today all over the world.(Liker, 2004). In 1980s, products were being brought to the market with higher quality and lower price. Consumers came to expect higher quality and lower prices as a requisite for purchase. Some manufacturers faded away while others began to look diligently for better ways to compete (Hobbs, 2004).

In order to compete in today's fiercely competitive market, US manufacturers have come to realize that the traditional mass production concept has to be adapted to the new ideas of lean manufacturing because the Japanese companies developed, produced and distributed products with half or less human effort, capital investment, floor space, tools, materials, time, and overall expense (Khatri, et.al, 2011).

\section{Literature Review}

The effect of lean manufacturing on cost of production has been addressed by a number of researchers. Saleh (2011) found that the five studied Iraqi manufacturing firms possibilities of establishing the lean foundations are different according to the availability of thinking capital and there is a positive relationship between the thinking capital and lean foundations for all of the studied firms. Badran (2010) concluded that managing the production processes is very important for all kinds of organizations in Syria (General and private organizations, manufacturing and service organizations). Forrester, et.al. (2010) stated that managers of the agricultural machinery sector in Brazil have supported a transition towards the adoption of lean manufacturing practices and they have shown a significant improvement in their business performance including the production cost. El-Kourd (2009) concluded that using lean construction in Gaza Strip reduced the number of steps in the whole project by $57 \%$, the non-value added decreased from $81 \%$ to $14 \%$ in the project duration, and the total cycle time of the project was reduced by $75 \%$. Enaghani, et.al. (2009) illustrated that lean is a culture for quality improvement starting with revolutionizing the minds of employees while TPM is a method in Ireland and Sweden. Hallgren and Olhager (2009) found that lean manufacturing has a significant impact on cost performance for the studied plants in 7 countries, whereas agile manufacturing has not, and agile manufacturing has a stronger relationship with volume than does lean manufacturing. Rathi (2009) concluded that unneeded processing, transportation of materials and WIP inventory wastes are significant in job type PI and raw material inventory was the most prevalent waste for the process industry sector. AlDabbagh and Hassan (2008) stated that the studied company in Iraq has an accepTable (knowledge concerning lean manufacturing, and the basic requirements to apply lean manufacturing are available in this company. Piercy and Rich (2008) illustrated that services call centers for the studied 3 financial services companies in the UK can serve the traditionally competing priorities both of operational cost reduction and increased customer service quality.
Czabke (2007) concluded that all plants became more efficient and hence more cost effective and profiTable (after implementing lean manufacturing in the US and Germany. McGrath (2007) found that both Irish companies have made some great improvements in terms of the value streams of their respective plants and also in the reduction of waste and inventory. Another result has been reached that lean manufacturing is a considered as a strategic tool to improve the competitive position of the organization. Berg and Ohlsson (2005) stated that overproduction is the most serious waste because it contributes to the other six wastes where production costs money and there is no reason to produce items that are not demanded. Koh, et.al. (2004) has reached to the conclusion that lower production costs can be achieved when lean production manufacturing practices, such as, TQM and JIT, are used. Stephen (2004) showed that the slow rate of corporate improvement is not due to lack of knowledge of six-sigma or lean. Rather, the fault lies in making the transition from theory to implementation. Yamashita (2004) concluded that higher quality products with less resources and capital are achieved by implementing lean manufacturing and lean manufacturing leads to reductions in scrap, rework, returns, and waste. Abdullah (2003) concluded that the driving force behind implementing lean in the US was the cost reduction for the steel companies (among others). Kilpatrick (1997) concluded that inventory increasing lead to ever increasing costs in the form of invested capital, damaged finished goods, scrapped product, and costly inventory control system. Also, eliminating all defects is crucial to minimize lead time was another conclusion. Joing (1995) concluded that on-time delivery and customer satisfaction improved while lead times and inventories dropped significantly.

\section{Problem and Hypothesis}

Managers of the manufacturing firms in Gaza Strip are focusing on the manufacturing processes or the value-added activities in order to improve their business profitability. On the other hand, they neglect the importance and effects of the non-value added activities (wastes) which are usually not explicitly visible. Therefore, the research main question is: What is the effect of lean manufacturing on the production cost for the manufacturing firms in Gaza Strip?

The research paper tested the study problem by using the following hypotheses:

There is a significant statistical effect for the seven wastes elimination targeted by lean manufacturing (overproduction, inventory, over-processing, motion, waiting, defects and transportation) on the production cost for the manufacturing firms in Gaza Strip.

\section{Objectives}

The main goal of the present research work is to investigate the current situation of wastes elimination in the manufacturing firms in Gaza Strip and its important role for 
reducing the production cost. Also, it aims to promote Lean thinking in Gaza Strip manufacturing firms, also, the research seeks to provide a comprehensive picture of the reality of the wastes elimination management and its multiple dimensions in the manufacturing firms and paving the way for officials to make steps and to develop policies to ensure the competition of the Palestinian industry.

\section{Lean Manufacturing Definition}

Lean manufacturing is defined as "A philosophy, based on Toyota Production System, and other Japanese management practices that strives to shorten the time line between the customer order and the shipment of the final product, by consistent elimination of waste". All types of companies, manufacturing, process, distribution, software development or financial services can benefit from adopting lean philosophy. As long as a company can identify a value stream, from when the customers order product to when they receive it, lean principles can be applied and waste removed (Singh, 1999). Also, lean manufacturing is: "Adding value by eliminating waste, being responsive to change, focusing on quality, and enhancing the effectiveness of work force" (Liker, 2004). Another definition for lean manufacturing: "it is a systematic approach to identify and eliminate waste (non-value added activities) through continuous improvement by following the product at the pull of the customer in pursuit of perfection" (Czarnecki and Loyd, 1998).

\section{Traditional vs. Lean Manufacturing}

For years manufacturers have created products in anticipation of having a market for them. Operations have traditionally been driven by sales forecasts and firms tended to stockpile inventories in case they were needed. A key difference in Lean Manufacturing is that it is based on the concept that production can and should be driven by real customer demand (Ibrahim, 2011).

A lean organization can make twice as much product with twice the quality and half the time and space, at half the cost, with a fraction of the normal work-in-process inventory. Lean management is about operating the most efficient and effective organization possible, with least cost and zero waste (Minggu, 2009).

Table 2. Methods of Manufacturing of Traditional Mass Production and Lean Manufacturing.

\begin{tabular}{|c|c|c|}
\hline Manufacturing Methods & Traditional Mass Production & Lean Production \\
\hline Production schedules are based on & Forecast-product is pushed through the facility & $\begin{array}{l}\text { Customer order-product is pulled through the facil- } \\
\text { ity }\end{array}$ \\
\hline Products manufactured to & Replenish finished goods inventory & Fill customer orders (immediate shipments) \\
\hline Production cycle times are & Weeks/month & Hours/days \\
\hline $\begin{array}{l}\text { Manufacturing lot size } \\
\text { quantities are }\end{array}$ & \multirow{2}{*}{\multicolumn{2}{|c|}{$\begin{array}{l}\text { Large, with large batches moving between operations; productSmall, and based on one-piece flow between Oper- } \\
\text { is sent a hard of each operation } \\
\begin{array}{ll}\text { By department function } & \text { By product flow, using cells or lines for product } \\
\text { families }\end{array}\end{array}$}} \\
\hline Plant and equipment layout is & & \\
\hline Quality is assured & Through lot sampling & $100 \%$ at the production source \\
\hline Workers are typically assigned & One person per machine & With one person handling several machines \\
\hline Workers empowerment is & Low-little input into how operation is performed & $\begin{array}{l}\text { High-has responsibility for identifying and imple- } \\
\text { menting improvements }\end{array}$ \\
\hline Inventory level are & \multicolumn{2}{|c|}{$\begin{array}{l}\text { High-large warehouse of finished goods, and central storeroomLow-small amounts between operations ship } \\
\text { for in- process staging }\end{array}$} \\
\hline Inventory turns are & Low-6-9 turns per year or less & High $20+$ turns per year \\
\hline $\begin{array}{l}\text { Flexibility in changing } \\
\text { manufacturing schedules is }\end{array}$ & Low-difficult to handle and adjust to & High-easy to adjust to and implement \\
\hline Manufacturing costs are & Rising and difficult to control & Stable/decreasing and under control \\
\hline
\end{tabular}

"Source: CIP, (2006). "Lean Manufacturing / Lean Production". http://www.dynamicbiz.us/366/article-leanmanufacturing.html".

\section{Main Kinds of Wastes}

Seven main types of wastes were identified as a part of the Toyota Production System. However, this list has been modified and expanded by various practitioners of lean manufacturing and generally includes the following:

\subsection{Overproduction}

It is unnecessary to produce more than the customer demands, or producing it too early before it is needed. This increases the risk of obsolescence and the risk of producing the wrong thing (Capital, 2004). It tends to lead to excessive lead and storage times. In addition, it leads to excessive work-in-process stocks which result in the physical dislocation of operations with consequent poorer communication (Hines and Rich, 2007).

\subsection{Defects}

In addition to physical defects which directly add to the costs of goods sold, this may include errors in paperwork, late delivery, production according to incorrect specifications, use of too much raw materials or generation of unnecessary scrap (Capital, 2004). When defect occurs, rework 
may be required; otherwise the product will be scrapped. Generation of defects will not only waste material and labor resources, but it will also create material shortages, hinder meeting schedules, create idle time at subsequent workstations and extend the manufacturing lead time (Rawabdeh, 2005).

\subsection{Inventory}

It means having unnecessarily high levels of raw materials, works-in-process and finished products. Extra inventory leads to higher inventory financing costs, higher storage costs and higher defect rates. (Capital, 2004). It tends to increase lead time, prevents rapid identification of problems and increase space requirements. In order to conduct effective purchasing, it is especially necessary to eliminate inventory due to incorrect lead times (Rawabdeh, 2005).

\subsection{Transportation}

It includes any movement of materials that does not add any value to the product, such as moving materials between workstations. Transportation between processing stages results in prolonging production cycle times, the inefficient use of labor and space (Capital, 2004). Any movement in the firms could be viewed as waste. Double handling and excessive movements are likely to cause damage and deterioration with the distance of communication between processes (Hines and Rich, 2007).

\subsection{Waiting}

It is idle time for workers or machines due to bottlenecks or inefficient production flow on the factory floor. It includes small delays between processing of units (Capital, 2004). When time is being used ineffectively, then the waste of waiting occurs. This waste occurs whenever goods are not moving or being worked on. This waste affects both goods and workers, each spending time waiting. Waiting time for workers may be used for training or maintenance activities and should not result in overproduction (Hines and Rich, 2007).

\subsection{Motion}

It includes any unnecessary physical motions or walking by workers which divert them from actual processing work. This might include walking around the factory floor to look for a tool, or even unnecessary or difficult physical movements, due to poorly designed ergonomics, which slow down the workers (Capital, 2004). It involves poor ergonomics of production, where operators have to stretch, bend and pick up when such actions could be avoided (Rawabdeh,
2005).

\subsection{Over-processing}

It is unintentionally doing more processing work than the customer requires in terms of product quality or featuressuch as polishing or applying finishing in some areas of product that will not be seen by the customer (Capital, 2004). Over-processing occurs in situations where overly complex solutions are found to simple procedures. The over-complexity discourages ownership and encourages employees to overproduce to recover the large investment in the complex machines (Hines and Rich, 2007).

\section{Palestinian Manufacturing Sector}

The development of the Palestinian manufacturing sector significantly led to a significant increase in its contribution to the GDP in Palestine that arrived the proportion of $(8 \%)$ during the Israeli occupation in the period from 1967 to 1991 , and $(16 \%)$ before Al-Aqsa Intifada of September,2000 (Nofal, 2001).

However, the manufacturing sector still suffers from dependence on the Israeli industry which affects its development. In addition, the Palestinian industrial sector has fallen substantially as a result for the Israeli actions since Al-Aqsa Intifada till now because of the closure and siege on the Palestinian areas in West Bank and Gaza Strip (PCBS, 2008).

Production had been decreased in all of the Palestinian industries in the West Bank and Gaza Strip. The industrial sector problems were not only due to the Israeli actions, but also the inability of the Palestinian Authority to develop an industrial strategy was a main cause. In addition, there were many obstacles that have prevented the self-development of this sector and its development, such as lack of raw materials, quality problems, lack of experience, the absence of regulation, the scarcity of natural materials, the problems of labor, and authority corruption (PCBS, 2008).

The shortage of raw materials led to the deterioration of the private sector and the closure of economic establishments. The proportion of establishments operating in the manufacturing sector stopped on a temporary basis was $70 \%$, while the number of establishments operating in part was approximately 50\% (IDS, 2010). Damages of economic activities led to a rise in unemployment to $39.7 \%$ during the first quarter of the year 2010, and the siege has led to the high cost of living index, the average prices during the first quarter of 2010 is about 131.34 points, i.e., the index rose by $51.4 \%$ compared to 2009 (IDS, 2010).

Table 3. Percentage Contribution to GDP by Manufacturing in Gaza Strip for the Years (From 1999 to 2009) 2004 is the base year.

\begin{tabular}{|c|c|c|c|c|c|c|c|c|c|c|c|}
\hline Economic Activity & 1999 & 2000 & 2001 & 2002 & 2003 & 2004 & 2005 & 2006 & 2007 & 2008 & 2009 \\
\hline Manufacturing & 12.8 & 6.0 & 13.8 & 16.5 & 14.8 & 13.2 & 12.4 & 9.7 & 7.0 & 10.6 & 7.9 \\
\hline
\end{tabular}


"gaza strip manufacturing firms"

Table 4. The Added Value (in \$USD million) by Manufacturing in Gaza Strip for the Years (From 1999 to 2009) 2004 is the base year.

\begin{tabular}{|c|c|c|c|c|c|c|c|c|c|c|}
\hline $\begin{array}{l}\text { Economic } \\
\text { Activity }\end{array}$ & 2000 & 2001 & 2002 & 2003 & 2004 & 2005 & 2006 & 2007 & 2008 & 2009 \\
\hline Manufacturing 174.9 & 46.4 & 107.6 & 109.3 & 132.1 & 113.9 & 126.3 & 85.2 & 33.3 & 28.1 & 28.2 \\
\hline
\end{tabular}

"Source: PCBS, (2010). The Annual Statistics of Palestine, 11th Edition".

\section{Research Methodology}

In order to test the research hypothesis and achieve the objectives, the researchers used secondary data such as books, journals and documents, thesis, and scientific websites specialized in eliminating wastes. Two sources were used to collect the primary data. First, Wastes Relations Matrix (WRM), was implemented through conducting a brainstorming session with three professional managers to answer special questions. WRM was illustrated and analyzed to show the relations among the seven wastes; this illustration and analysis are based on literature review and the answers of the brainstorming group. It was used to test the main research hypothesis.

Second, a questionnaire (shown in Appendix A) was distributed to the top management of all of the manufacturing firms having more than nine fixed employees in the Gaza Strip, and the researcher offloaded and analyzed the results and resolution through the use of the statistical procedures.

The last census of the manufacturing firms in the Gaza Strip prepared in 2007 shows that the total number of the related firms having more than nine fixed employees is 204. As a result of destroying many firms by the military aggression in the Gaza Strip (Dec., 2008 to Jan., 2009) and closure of other firms during the last period, the researcher surveyed all of the found related firms in the Gaza Strip and their total number was 114. (Respondents were 99 out of 114).

Study population: the top management of all of the manufacturing firms having more than nine fixed employees in the Gaza Strip, the researchers surveyed all of the population and their total number was 114. (Respondents were 99 out of 114).

The researchers think that all types of wastes are dependent, since each type of waste has its own influence on others and at the same time is influenced by others and resulting in increasing the cost of production.

For testing this idea, each type of wastes was denoted using its first letter, where (O: Over-production, I: Inventory, P: Over-processing, M: Motion, W: Waiting, D: Defects, T: Transportation).

Then, each relation was assigned by the symbol "i j", where:

- (i): one of the seven wastes

- (j): the other six wastes

For instance, "O_I" indicates the direct effect of overproduction on inventory, and so on.

Note that some relations will not be discussed because the brainstorming group thinks that there is no direct effect of (i) on (j).

\section{Wastes Dependence}

\subsection{Overproduction Waste}

"O_I": Over-production means high raw material inventory, increases the work-in-process, and requires more storage of equipment and handling tools. Also, producing more products requires high finished products storage.

"O_D": Because of the higher production rate, the probability of raw materials defects increases. When the operator produces more, less effort will be spent on each unit which leads to less quality and more defects.

"O_M": Over-production causes excess workers motions during process. When the operator produces more, improper ergonomics motions increase.

"O_T": Over-production means more transportation from the raw materials store to the production floor, more transportation between the various production stages. Also, overproduction means more transportation of the finished products to warehouse.

"O_W": Over-production increases the waiting of semi-finished products between machines. Meanwhile overproduction increases operator waiting during the production process. Overproduction may increase machines breakdown, which means waiting for maintenance.

\subsection{Inventory Waste}

"I_O": High level existence of raw materials in inventory pushes firms to produce not according to the market quantity demanded.

"I_D": Raw materials inventory for a long time increases defects. Inventory between production processes on the shop floor increases the probability of semi-product damage. Storing of the finished products in warehouse for a long time may cause product damage.

"I_M": Higher levels of work-in-process increase the time for searching, selecting, grasping, reaching, moving, and handling.

"I_T": High levels of inventory mean more transportation between the store and the production floor. High levels of work-in-process inventory increase the transportation between workstations and obstruct the movement on the shop floor.

\subsection{Defects Waste}

"D_O": Increasing the number of defects pushes to produce more parts to consume the loss.

"D_I": As defective parts increase, the WIP level increases. 
"D_M": Defective parts require a repairing process for them which requires workers motion.

"D_T": Repairing defective parts increases transportation efforts.

"D_W": Producing defective parts requires to explore the causes of errors and to take corrective actions therefore, other parts will wait to be processed.

\subsection{Motion Waste}

"M_I": Insufficient workers motions cause accumulating work-in-process.

"M_D": Insufficient workers motions during production increase numbers of defect parts . Unskilled and untrained proper motions workers increase defects.

"M_P": When jobs are non-standardized, there will be an opportunity of over-processing. Process waste will also be increased due to lack understanding, the available technology capacity.

"M_W": When there are no standard motions of the workers during production process, the required time to processed next part increases.

\subsection{Transportation Waste}

"T_O": Items are produced more than needed to fill materials handling equipment in order to reduce the transporting cost per unit and to minimize the number of transports.

"T I": If there are no sufficient methods and number of equipments for transportation, work-in-process inventory increases.

"T_D": Insufficient transportation methods and unsafe transportation equipments increase the probability of production defects, also improper handling of the products may cause parts damage.

"T_M": insufficient and non-standardized transportation methods increase the workers motions by double handling and searching.

"T W": When the transportation is not on time or ineffective, waiting time for parts to be transported increases.

\subsection{Overprocessing Waste}

"P_O": An important aspect of process waste in order to reduce operation cost per machine time, machines are pushed to operate full time shift which finally results in overproduction.

"P_I": Combining operations in one cell will decrease WIP amounts because of eliminating buffers.

"P_D": Insufficient and improper processes lead to produce defects.

"P M": Non-standardized process requires more worker motions

"P_W": UnsuiTable (technology used, by means of high setup times and adjustments or repetitive downtimes, leads to higher waiting times.

\subsection{Waiting Waste}

"W_O" When a machine is waiting because its supplier is serving another customer, the machine is forced to produce more just to keep running.

"W_I" Waiting of parts between workstations increases work-in-process. Also, waiting of the finished items in warehouse increases inventory.

"W_D": Waiting of parts in work-in-process inventory may cause defects due to the surrounding conditions.

"W_M": Waiting of parts in work-in-process inventory may cause unnecessary motion of workers and machines.

\section{Strength of Waste Relations}

The numerous types of relations and each type nature suggests that, all of these relations are not equal weights. The need to assign weights relations, is justified by knowing which type of waste contributes more to the wasteful activities in the shop floor. Criterion was set to measure strength of waste relations.

\section{Measurement Criterion Develop- ment}

The Criterion consists of six developed questions; each answer has a certain weight from one to five as follows:

Note: "i" stand for any type of waste affects on "j", which is the other type of waste.

Question

Weight

1- Does i produce j?

a. Always

b. Sometimes

c. Rarely

2- What is the type of the relation between $\mathbf{i}$ and $\mathbf{j} ?{ }_{5}$ a. As i increases, $\mathrm{j}$ increases

b. As i increases, $\mathrm{j}$ reaches a constant level ${ }_{1}^{3}$

c. Random relation according to condi- ${ }_{5}$ tions

3- The effect of $j$ due to $i$ :

a. Appears directly and clearly.

b. Often appears, but needs time to do

c. Rarely appears with along time

4- Eliminating the effect of $\mathbf{i}$ on $\mathbf{j}$ is achieved by:

a. Engineering and complex methods

b. Simple and direct

c. Only by an instruction

5- The effect of $j \mathbf{j}$ due to $i$, mainly influences on:

a. Quality of products only

b. Productivity of Resources only

c. Lead time only

d. Quality and productivity

e. Productivity and lead time

f. Quality and lead time

g. Quality, productivity and lead time

6- In which degree does the effect of $i$ on $\mathbf{j}$ increas- ${ }^{3}$ es Manufacturing Lead time?

a. High degree

b. Medium degree

c. Low degree 


\section{Measurement Criterion Analysis and Results}

The criterion was applied on all of the relations and the analyses were carried out using the following steps:

Step (1): Answering each question with respect to each discussed relation.

The answer of questions (1-6), with respect to overproduction and inventory (O_I), where "b" for question (1), "b" for question (2) and so on.

\begin{tabular}{|c|c|c|c|c|c|c|c|c|}
\hline Question & & 2 & & 3 & 4 & 5 & 6 & Rela- \\
\hline $\begin{array}{l}\text { Rela- } \\
\text { tions }\end{array}$ & $\begin{array}{l}\text { Ans } \\
.\end{array}$ & $\begin{array}{l}\text { t An } \\
.\end{array}$ & $\begin{array}{l}W \\
t\end{array}$ & $\begin{array}{l}\text { An } \\
.\end{array}$ & $\begin{array}{c}\mathbf{N t} \text { An } \\
.\end{array}$ & $\begin{array}{c}\mathrm{Wt} \text { An } \\
.\end{array}$ & $\begin{array}{l}\text { Wt Ans Wt } \\
. \quad . \quad . \\
\end{array}$ & tion \\
\hline O_I & B & B & & B & $\mathrm{a}$ & $\mathrm{E}$ & $\mathrm{c}$ & \\
\hline O D & C & $\mathrm{C}$ & & $\mathrm{C}$ & $\mathrm{a}$ & $\mathrm{C}$ & $\mathrm{c}$ & \\
\hline
\end{tabular}

Step (2): each answer was assigned its own weight mentioned in the measurement criterion. Each number besides each character represents the weight of the answer. All numbers were separated in single columns representing weights.

\begin{tabular}{|c|c|c|c|c|c|c|c|c|c|c|c|c|c|}
\hline Question & & & 2 & & 3 & & 4 & & 5 & & 6 & Scar & Rela- \\
\hline $\begin{array}{l}\text { Rela- } \\
\text { tions }\end{array}$ & $\begin{array}{l}\text { Ans } \\
.\end{array}$ & & $\begin{array}{c}\mathrm{tAn} \\
.\end{array}$ & $\begin{array}{c}\text { is W } \\
\text { t }\end{array}$ & $\begin{array}{l}V \mathrm{An} \\
\text {. }\end{array}$ & & $\begin{array}{l}\text { t An } \\
.\end{array}$ & & $\begin{array}{l}\text { t Ans } \\
.\end{array}$ & & & & tion \\
\hline O_I & B & 3 & B & 3 & B & 3 & $\mathrm{a}$ & 5 & $\mathrm{E}$ & 3 & $\mathrm{c}$ & 1 & \\
\hline O D & $\mathrm{C}$ & $\mathrm{C}$ & 1 & $\mathrm{C}$ & 1 & $\mathrm{C}$ & a & 5 & $\mathrm{C}$ & 1 & $\mathrm{c}$ & 1 & \\
\hline
\end{tabular}

Step (3): the weighting of all answers of each relation were added together, resulting to the overall summations.

\begin{tabular}{|c|c|c|c|c|c|c|c|c|c|c|c|c|c|c|}
\hline Question & & & 2 & & 3 & & 4 & & 5 & & 6 & & & \\
\hline $\begin{array}{l}\text { Rela- } \\
\text { tions }\end{array}$ & $\begin{array}{l}\text { Ans } \\
\text {. }\end{array}$ & $\begin{array}{c}\text { is Wt } \\
\text {. }\end{array}$ & $\begin{array}{c}\mathrm{t} \text { An } \\
.\end{array}$ & $\begin{array}{c}s \text { W } \\
t\end{array}$ & $\begin{array}{l}\text { An } \\
\text {. }\end{array}$ & & $\begin{array}{c}\text { t An } \\
.\end{array}$ & $\begin{array}{c}\mathbf{s} \mathbf{W} \\
.\end{array}$ & $\begin{array}{l}\text { t Ans } \\
\text {. }\end{array}$ & & $\begin{array}{l}\text { Ans } \\
\text {. }\end{array}$ & & & tion \\
\hline O_I & B & 3 & $\mathrm{~B}$ & 3 & $\mathrm{~B}$ & 3 & $\mathrm{a}$ & 5 & $\mathrm{E}$ & 3 & $\mathrm{c}$ & 1 & 18 & \\
\hline O_D & $\mathrm{C}$ & $\mathrm{C}$ & 1 & $\mathrm{C}$ & 1 & $\mathrm{C}$ & $\mathrm{a}$ & 5 & $\mathrm{C}$ & 1 & $\mathrm{c}$ & 1 & 10 & \\
\hline
\end{tabular}

Step (4): the score indicates the strength of each relation. In order to distinguish among the different relations, it was noticed that the higher score represent stronger relation and vice versa.

Table 5. The Range Divisions of Strength of Direct Relations.

\begin{tabular}{lll}
\hline Range & Type of Relation & Symbol \\
\hline 26 To 30 & Absolutely Necessary & $A$ \\
21 To 25 & Especially Important & $E$ \\
16 To 20 & Important & $I$ \\
11 To 15 & Ordinary Closeness & $O$ \\
6 To 10 & Unimportant & $U$ \\
\hline
\end{tabular}

Step (5): the scores were translated into symbols representing the different relations. Table (6) shows the
Measurement Criterion Question's Answers (done by brainstorming):

Table 6. The Measurement Criterion Question's Answers.

\begin{tabular}{|c|c|c|c|c|c|c|c|c|c|c|c|c|c|c|}
\hline \multicolumn{3}{|c|}{ Question1 } & \multicolumn{2}{|c|}{2} & \multicolumn{2}{|c|}{3} & \multicolumn{2}{|c|}{4} & & \multicolumn{2}{|l|}{6} & t $_{\mathrm{e}}^{\text {Scor }}$ & \multirow{2}{*}{$\begin{array}{l}\text { Rela- } \\
\text { tion }\end{array}$} \\
\hline $\begin{array}{l}\text { Rela- } \\
\text { tions }\end{array}$ & $\begin{array}{l}\text { A } \\
\text {. }\end{array}$ & $\begin{array}{c}\text { s W } \\
.\end{array}$ & $\begin{array}{l}\mathrm{tA} \\
.\end{array}$ & $\begin{array}{c}\mathrm{S} \mathrm{Y} \\
.\end{array}$ & $\begin{array}{c}\text { t A } \\
.\end{array}$ & $\begin{array}{r}\mathrm{s} \mathrm{H} \\
.\end{array}$ & $\mathrm{A}$ & $\begin{array}{c}\text { s W } \\
.\end{array}$ & $\begin{array}{l}\mathrm{A} \\
.\end{array}$ & $\begin{array}{l}\text { SW } \\
.\end{array}$ & $\begin{array}{l}\mathrm{A} \\
.\end{array}$ & $\begin{array}{l}\mathbf{W} \\
\end{array}$ & & \\
\hline O_I & $\mathrm{b}$ & 3 & $\mathrm{~b}$ & 3 & B & 3 & $\mathrm{a}$ & 5 & e & 3 & $\mathrm{c}$ & 1 & 18 & I \\
\hline O_D & $\mathrm{c}$ & 1 & $\mathrm{c}$ & 1 & C & 1 & a & 5 & $\mathrm{c}$ & 1 & $\mathrm{c}$ & 1 & 10 & $\mathrm{U}$ \\
\hline O_M & b & 3 & $\mathrm{a}$ & 5 & A & 5 & a & 5 & a & 1 & $\mathrm{c}$ & 1 & 20 & I \\
\hline O_T & b & 3 & $\mathrm{c}$ & 1 & $\mathrm{C}$ & 1 & $\mathrm{a}$ & 5 & $\mathrm{~g}$ & 5 & $\mathrm{~b}$ & 3 & 18 & I \\
\hline O_W & $\mathrm{b}$ & 3 & $\mathrm{a}$ & 5 & B & 3 & $\mathrm{a}$ & 5 & e & 3 & $\mathrm{~b}$ & 3 & 22 & $\mathrm{E}$ \\
\hline I_O & $\mathrm{c}$ & 1 & $\mathrm{c}$ & 1 & $\mathrm{C}$ & 1 & $\mathrm{c}$ & 1 & $b$ & 1 & $\mathrm{c}$ & 1 & 6 & $\mathrm{U}$ \\
\hline I_D & $\mathrm{b}$ & 3 & $\mathrm{c}$ & 1 & B & 3 & b & 3 & $b$ & 1 & $\mathrm{c}$ & 1 & 12 & $\mathrm{O}$ \\
\hline I_M & $\mathrm{a}$ & 5 & $\mathrm{a}$ & 5 & A & 5 & $\mathrm{a}$ & 5 & $\mathrm{~g}$ & 5 & $\mathrm{a}$ & 5 & 30 & A \\
\hline I_T & $\mathrm{b}$ & 3 & $\mathrm{~b}$ & 3 & B & 3 & b & 3 & $\mathrm{a}$ & 1 & $\mathrm{c}$ & 1 & 14 & $\mathrm{O}$ \\
\hline D_I & $\mathrm{a}$ & 5 & $\mathrm{a}$ & 5 & A & 5 & $\mathrm{a}$ & 5 & $\mathrm{~g}$ & 5 & $\mathrm{a}$ & 5 & 30 & A \\
\hline D_O & $\mathrm{b}$ & 3 & $\mathrm{c}$ & 1 & B & 3 & b & 3 & e & 3 & $\mathrm{~b}$ & 3 & 16 & I \\
\hline D_M & $\mathrm{a}$ & 5 & $\mathrm{a}$ & 5 & A & 5 & $\mathrm{c}$ & 1 & e & 3 & $\mathrm{~b}$ & 3 & 22 & $\mathrm{E}$ \\
\hline D_T & $\mathrm{a}$ & 5 & $\mathrm{a}$ & 5 & A & 5 & b & 3 & e & 3 & $\mathrm{~b}$ & 3 & 24 & $\mathrm{E}$ \\
\hline D_W & $\mathrm{a}$ & 5 & $\mathrm{a}$ & 5 & B & 3 & b & 3 & e & 3 & a & 5 & 24 & $\mathrm{E}$ \\
\hline M_I & $\mathrm{c}$ & 1 & $\mathrm{a}$ & 5 & B & 3 & $\mathrm{c}$ & 1 & e & 3 & $\mathrm{c}$ & 1 & 16 & I \\
\hline M_D & $b$ & 3 & $\mathrm{~b}$ & 3 & B & 3 & $\mathrm{a}$ & 5 & $\mathrm{~g}$ & 5 & $\mathrm{a}$ & 5 & 24 & $\mathrm{E}$ \\
\hline M_W & $\mathrm{a}$ & 5 & $\mathrm{a}$ & 5 & A & 5 & a & 5 & e & 3 & $\mathrm{a}$ & 5 & 28 & A \\
\hline M_P & $\mathrm{b}$ & 3 & $\mathrm{~b}$ & 3 & A & 5 & C & 1 & d & 3 & $\mathrm{~b}$ & 3 & 18 & I \\
\hline T_O & $\mathrm{b}$ & 3 & $\mathrm{c}$ & 1 & $\mathrm{C}$ & 1 & b & 3 & e & 3 & $\mathrm{c}$ & 1 & 12 & $\mathrm{O}$ \\
\hline T_I & $\mathrm{b}$ & 3 & $\mathrm{~b}$ & 3 & B & 3 & b & 3 & e & 3 & $\mathrm{~b}$ & 3 & 18 & I \\
\hline T_D & $\mathrm{b}$ & 3 & $\mathrm{c}$ & 1 & A & 5 & $b$ & 3 & e & 3 & $b$ & 3 & 18 & I \\
\hline T_M & $\mathrm{a}$ & 5 & $\mathrm{~b}$ & 3 & A & 5 & b & 3 & c & 1 & $\mathrm{~b}$ & 3 & 20 & I \\
\hline $\mathrm{T}_{-} \mathrm{W}$ & $b$ & 3 & $\mathrm{a}$ & 5 & B & 3 & $\mathrm{~b}$ & 3 & e & 3 & $\mathrm{~b}$ & 3 & 20 & I \\
\hline P_O & $\mathrm{c}$ & 1 & $\mathrm{c}$ & 1 & B & 3 & b & 3 & c & 1 & $\mathrm{~b}$ & 3 & 12 & $\mathrm{O}$ \\
\hline$P_{-} \mathrm{I}$ & $\mathrm{c}$ & 1 & $\mathrm{~b}$ & 3 & B & 3 & $\mathrm{~b}$ & 3 & $\mathrm{f}$ & 3 & $\mathrm{c}$ & 1 & 14 & $\mathrm{O}$ \\
\hline P_D & $b$ & 3 & $\mathrm{c}$ & 1 & B & 3 & b & 3 & $\mathrm{f}$ & 3 & $\mathrm{~b}$ & 3 & 16 & I \\
\hline P_M & $\mathrm{b}$ & 3 & $\mathrm{c}$ & 1 & $\mathrm{C}$ & 1 & $\mathrm{c}$ & 1 & e & 3 & $\mathrm{c}$ & 1 & 10 & $\mathrm{U}$ \\
\hline $\mathrm{P}_{-} \mathrm{W}$ & $\mathrm{b}$ & 3 & $\mathrm{c}$ & 1 & A & 5 & b & 3 & e & 3 & $\mathrm{~b}$ & 3 & 18 & I \\
\hline W_O & b & 3 & $\mathrm{a}$ & 5 & B & 3 & $a$ & 5 & $\mathrm{~g}$ & 5 & $\mathrm{~b}$ & 3 & 24 & E \\
\hline W_I & $\mathrm{a}$ & 5 & $\mathrm{a}$ & 5 & A & 5 & $\mathrm{c}$ & 1 & e & 3 & $\mathrm{~b}$ & 3 & 22 & $\mathrm{E}$ \\
\hline W_D & $\mathrm{a}$ & 5 & $\mathrm{a}$ & 5 & A & 5 & $\mathrm{a}$ & 5 & e & 3 & b & 3 & 26 & A \\
\hline W_M & $\mathrm{c}$ & 1 & $\mathrm{c}$ & 1 & $\mathrm{C}$ & 1 & $\mathrm{C}$ & 1 & b & 1 & $\mathrm{c}$ & 1 & 6 & $\mathrm{U}$ \\
\hline
\end{tabular}

\section{Hypothesis Testing by Applying}


WRM

\subsection{WRM Scores}

WRM organizes what was obtained through the criterion.

Table 7. Waste Relation Matrix.

\begin{tabular}{llllllll}
\hline F/T & O & I & D & M & T & P & W \\
O & & I & U & I & I & X & E \\
I & U & & O & A & O & X & X \\
D & I & A & & E & E & X & E \\
M & X & I & E & & X & I & A \\
T & O & I & I & I & & X & I \\
P & O & O & I & U & X & & I \\
W & E & E & A & U & X & X & \\
\hline
\end{tabular}

Note: The symbol " $X$ " indicates that there is no direct effect of (i) on (j).

Each row shows the effect of a certain waste on the other six wastes; similarly each column shows to what degree a certain type of waste is affected by others.

\subsection{Matrix Value}

The waste matrix represents real relationships among wastes. It may be used in several decision-making processes aiming toward waste allocation in the manufacturing firms, to prove this, weights were assigned to the relations. Furthermore, similar relations were assigned a new score out of 10; these scores are shown in Table (8).
Table 8. Matrix Value.

\begin{tabular}{ll}
\hline Type of relation & Weight \\
\hline A & 10 \\
E & 8 \\
I & 6 \\
O & 4 \\
U & 2 \\
X & 0 \\
\hline
\end{tabular}

The weights of each row and column were added to obtain the score, and then the percentages were calculated by dividing each score by the total score. These percentages represent the probability that a certain type of waste will affect others or be affected by others. Table (9) summarizes the previous analysis:

Table 9. Weights of Direct Waste Relations.

\begin{tabular}{llllllllll}
\hline $\mathbf{F} / \mathbf{T}$ & $\mathbf{O}$ & $\mathbf{I}$ & $\mathbf{D}$ & $\mathbf{M}$ & $\mathbf{T}$ & $\mathbf{P}$ & $\mathbf{W}$ & \multicolumn{2}{c}{ Score $\%$} \\
\hline $\mathrm{O}$ & & 6 & 2 & 6 & 6 & 0 & 8 & 28 & 14.3 \\
$\mathrm{I}$ & 2 & & 4 & 10 & 4 & 0 & 0 & 20 & 10.2 \\
$\mathrm{D}$ & 6 & 10 & & 8 & 8 & 0 & 8 & 40 & 20.4 \\
$\mathrm{M}$ & 0 & 6 & 8 & & 0 & 6 & 10 & 30 & 15.3 \\
$\mathrm{~T}$ & 4 & 6 & 6 & 6 & & 0 & 6 & 28 & 14.3 \\
$\mathrm{P}$ & 4 & 4 & 6 & 2 & 0 & & 6 & 22 & 11.2 \\
$\mathrm{~W}$ & 8 & 8 & 10 & 2 & 0 & 0 & & 28 & 14.3 \\
Score & 22 & 40 & 36 & 34 & 20 & 6 & 38 & 196 & 100 \\
$\%$ & 11.2 & 20.4 & 18.4 & 17.3 & 10.2 & 3.1 & 19.4 & 100 & \\
\hline
\end{tabular}

\subsection{WRM Results}

Table (9) confirms that there is a significant effect for all of the seven mentioned wastes on the production cost for the manufacturing firms in Gaza Strip.

Table 10. The Ranking of the Wastes that Affect on the Other Wastes.

\begin{tabular}{lllllll}
\hline $\begin{array}{l}\text { The } \\
\text { Primary Source }\end{array}$ & $\mathbf{1}^{\text {st }}$ Waste & $\mathbf{2}^{\text {nd }}$ Waste & $\mathbf{3}^{\text {rd }}$ Waste & $\mathbf{4}^{\text {th }}$ Waste & $\mathbf{5}^{\text {th }}$ Waste & $\mathbf{6}^{\text {th }}$ Waste \\
\hline WRM & Defects & Motion & Each of: Waiting+ Transportation+ Over-production & Processing & Inventory \\
\hline
\end{tabular}

Table 11. The Ranking of the Wastes Affected by the Other Wastes.

\begin{tabular}{llll}
$\begin{array}{l}\text { The } \\
\text { Primary } \\
\text { Source }\end{array}$ & $\mathbf{1}^{\text {st }}$ Waste & $\mathbf{2}^{\text {nd }}$ Waste & $\mathbf{3}^{\text {rd }}$ Waste \\
\hline WRM & Inventory & Waiting & Defects \\
\hline \multicolumn{4}{l}{$\begin{array}{l}\text { 6. Results and Conclusions Using } \\
\text { Questionnaire }\end{array}$}
\end{tabular}

The researchers used quantitative data analysis methods. The Data analysis will be made utilizing (SPSS 18). The researcher would utilize the following statistical tools:

1. Alpha Cronbach's and Split-Half Methods for Relia bility Statistics. 
then the mean of a paragraph is significantly different from a hypothesized value 3 . The sign of the Test value indicates

whether the mean is significantly greater or smaller than hypothesized value 3 . On the other hand, if the P-value (Sig.) is greater than the level of significance, $\alpha=0.05$, then the mean a paragraph is insignificantly different from a hypothesized value 3 .

- Kruskal-Wallis test is used to examine if there is a statistical significant difference between several means among the respondents toward Lean Manu- facturing attributed to (age, Specialization, Scientific qualification, and Position).

Hypothesis H1: There is a significant statistical effect of lean manufacturing on the production cost.

Table (12 shows the mean of all paragraphs of the questionnaire equals $4.07(81.32 \%)$, Test-value $=9.08$, and $\mathrm{P}$-value $=0.000$ which is smaller than the level of significance $\alpha=0.05$. The sign of the test is positive, so the mean of all paragraphs of the questionnaire is significantly greater than the hypothesized value 3 .

Table 12. shows: The Ranking of the Wastes that Affect on the Other Wastes.

\begin{tabular}{|c|c|c|c|c|c|c|}
\hline Primary Source & $1^{\text {st }}$ Waste & $2^{\text {nd }}$ Waste & $3^{\text {rd }}$ Waste & $5^{\text {th }}$ Waste & $6^{\text {th }}$ Waste & $7^{\text {th }}$ Waste \\
\hline $\begin{array}{l}\text { Wastes } \\
\text { Relationships Matrix }\end{array}$ & Defects & Motion & Each of: Waiting + Transportation + & Over-production & Processing & Inventory \\
\hline
\end{tabular}

This finding agrees with Forrester, et.al. (2010) who investigated the relationship between the adoption of lean manufacturing, market share, and value creation of companies in the agricultural machinery and implements sector in Brazil and reached to the conclusion that Brazilian firms and managers in this sector that have supported a transition towards the adoption of lean manufacturing practices have shown a significant improvement in their business performance including the production cost.

Moreover, this finding agrees with Hallgren and Olhager (2009) who investigated internal and external factors that drive the choice of lean and agile operation capabilities and their impact on operational performance. In this research, the impact on quality, delivery, cost, and flexibility performance was analyzed using equations modeling for a total of 211 plants from 3 industries and 7 countries. In this research, the researcher has reached to the conclusion that lean manufacturing has a significant impact on cost performance.

Also, this result agrees with Czabke (2007) who identified the common and individual pitfalls and difficulties during lean implementation for two lean leader companies from US and another two lean leader companies from Germany, where personal interviews -with the same questions- of high level management were the main source of information. The researcher found that all plants became more efficient and hence more cost effective and profiTable (by implementing lean manufacturing techniques.

This result is consistent with McGrath (2007) who determined the extent to which the main principles of lean manufacturing have been and/or still being carried out on two medical device companies based in the South of Ireland. Interviews were carried out there, and the respondents were chosen for their experience and expertise in lean manufacturing and production areas, and the researcher reached to the conclusion that both companies have made some great improvements in terms of the value streams of their respective plants and also in the reduction of wastes.

Also, This result is supported with Rawabdeh (2005) who investigated the waste in a job shop environment and proposes an assessment method aimed at helping companies to identify root causes of waste, and the researcher has developed a model that serves as a guideline for simplifying the search of wastes problems and identifies opportunities for waste elimination to improve the job shop performance.

Moreover, this finding agrees with Koh, et.al. (2004) who re-examined if lean production manufacturing practices interact with the compensation system and information system to reduce production costs, and reached to the conclusion that lower production costs can be achieved when lean production manufacturing practices, such as, TQM and JIT, are used.

Also, this result is consistent with Yamashita (2004) who determined how the consultant of (SAMA) is implementing the lean manufacturing process based on the company and focused on behaviors that organizations must exhibit to correctly implement and sustain lean manufacturing practices in Minneapolis area. The researcher found that higher quality products with less recourses and capital are achieved by implementing lean manufacturing which also leads to reductions in scrap, rework, returns, and waste.

Also, this result is consistent with Abdullah (2003) who investigated how lean manufacturing tools can be adapted from the discrete to the continuous manufacturing environment on a large steel manufacturing company. This research concluded that for the steel companies (as with others), the driving force behind implementing lean was cost reduction.

So, it is so clear now that lean manufacturing, which is a systematic approach to identify and eliminate waste (non-value added activities) through continuous improvement by following the product at the pull of the customer in pursuit of perfection, results in a significant cost. In the Gaza Strip, the researcher thinks that following the mentioned tools and techniques in chapter2 would also lead to high improvements in lead time, productivity, work-in-process inventory, quality, space utilization, processing errors, staffing demands, opportunities for new marketing campaigns, scrap, cross-trained employees, self-directed work teams, fast market response, longer machine life, customer communication, flexibility in reacting to changes, and strategic management focus. 


\begin{tabular}{lclll}
\hline Field & Mean & $\begin{array}{l}\text { Proportional } \\
\text { mean } \\
\text { (\%) }\end{array}$ & Test value & $\begin{array}{l}\text { P-value } \\
\text { (Sig.) }\end{array}$ \\
\hline Over-production & 4.09 & 81.79 & 8.96 & $0.000^{*}$ \\
Inventory & 3.98 & 79.57 & 8.30 & $0.000^{*}$ \\
Over-processing & 4.02 & 80.33 & 8.44 & $0.000^{*}$ \\
Motion & 4.15 & 83.01 & 9.02 & $0.000^{*}$ \\
Waiting & 4.11 & 82.10 & 8.86 & $0.000^{*}$ \\
Defects & 4.18 & 83.56 & 8.97 & $0.000^{*}$ \\
Transportation & 4.10 & 81.94 & 8.50 & $0.000^{*}$ \\
All paragraphs of the 4.07 & 81.32 & 9.08 & $0.000^{*}$ \\
\hline
\end{tabular}

Table (12; Means of all paragraphs of the questionnaire

As a result of this research, the role of lean manufacturing in developing the manufacturing business was emphasized, and evidence was provided to support the conceptual model to link between wastes elimination and reducing production.

Table 13. shows: The Ranking of the Wastes Affected by the Other Wastes.

\begin{tabular}{|c|c|c|c|c|c|}
\hline $\begin{array}{l}\text { The } \\
\text { Primary- } \\
\text { Source }\end{array}$ & $\begin{array}{l}1^{\text {st }} \\
\text { Waste }\end{array}$ & $\begin{array}{l}2^{\text {nd }} \quad 3^{\text {rd }} \\
\text { Wast Wast } \\
\text { e } \quad \text { e }\end{array}$ & $4^{\text {th }}$ Waste $^{5^{\text {th }} \text { Waste }}$ & $6^{\text {th }}$ Waste & $\begin{array}{l}7^{\text {th }} \\
\text { Waste }\end{array}$ \\
\hline WRM & $\begin{array}{l}\text { Inven- } \\
\text { tory }\end{array}$ & $\begin{array}{l}\text { Wait- De- } \\
\text { ing fects }\end{array}$ & $\begin{array}{l}\text { Mo- Over-produ } \\
\text { tion ion } \\
\end{array}$ & $\begin{array}{l}\text { ctTransporta } \\
\text { tion }\end{array}$ & $\begin{array}{l}\text { - Processi } \\
\text { ng }\end{array}$ \\
\hline
\end{tabular}

1. It is hoped that this research will provide the manufacturing managers within the suiTable (tools and techniques of eliminating wastes, such as, 5S's system, VSM, TPM, and JIT. Also, it is so necessary for them to implement these techniques which lead to huge improvement in their production.

2. Managers should train all of their employees in all of the managerial levels about applying lean manufacturing tools and techniques.

3. All of the wastes in the manufacturing firm have to be studied and analyzed separately to be able to apply lean manufacturing tools and techniques to reduce the production cost.

4. The manufacturing firms should develop their general plans and schedules according to the nature of their production to be able to reduce production costs.

5 . The production cost management must be included into the tasks of a department in the manufacturing firm. Sometimes, it is needed to be a special department.

\section{References}

[1] Jeffrey K. Liker, (2004). The Toyota Way, Published by Tata McGraw-Hill, ISBN 0-07-139231-9.

[2] Meyers, F., and Stewart, J., (2002). Motion and time study for lean manufacturing, 3rd Edition.

[3] The Palestinian Central Bureau of Statistics, (2010). The Annual Statistics of Palestine, 11th Edition.

[4] Capital, M., (2004). Introduction to Lean Manufacturing for Vietnam, Published Article by Mekong Capital Ltd.
[5] Czarnecki, H. and Loyd, N.,( 2004). Simulation of Lean Assembly Line for High Volume Manufacturing, Research Paper Published by University of Alabama in Huntsville.

[6] Dennis P. Hobbs, (2004). Lean Manufacturing Implementation: A complete execution manual for any size manufacturer, Published by J. Ross.

[7] Dimple Khatri, Pardeep Dhull, Rajender Kumar, and Vinod Dhull, (2011). Reduce the Work in Progress by Using Value Stream Mapping, Research Paper Published by International Journal of Mechanical Engineering Applications Research, Vol.2.

[8] Forrester, P., Shimizu, U., Meier, H., Reyes, J., and Basso, L., (2010). Lean Production, Market Share, and Value Creation in the Agricultural Machinery Sector in Brazil, Research Paper Published by Journal of Manufacturing Technology Management, Vol.21, No.7, pp.853-871.

[9] Hian Chye Koh, Khim Ling Sim, and Larry N. Killough (2004). The Interaction Effects of Lean Production Manufacuring Practices, Compensation, and Information Systems on Production Costs, Research Paper Published by Journal of Advances in Management Accounting, Vol.12, pp.115-135.

[10] Ibrahim Rawabdeh, (2005). A Model for the assessment of Waste in Job Shop Environments, Research Paper Published by International Journal of Operations and Production Management, Vol.25, No.8, pp.800-822.

[11] Jorge Leon, (1999). Toyota Production System and Lean Manufacturing, Published by Texas A\&M University.

[12] Mary Poppendieck, (2002). Principles of Lean Thinking, Published by Poppendieck.LLC.

[13] Mattias Hallgren and Jan Olhager, (2009). Lean and Agile Manufacturing: External and Internal Drivers and Performance Outcomes, Research Paper Published by International Journal of Operations and Production Management, Vol.29, No.10, pp.976-999.

[14] Mohammed AlDabbagh and Safwan Hassan, (2008). The Requirements of Implementing Lean Manufacturing for the Iraqi Industries, Published by University of Mosul.

[15] Niall Piercy and Nick Rich, (2008). High Quality and Low Cost: The Lean Service Centre, Research Paper Published by European Journal of Marketing, Vol.43, No.11/12, pp.1477-1497.

[16] Osama Nofal, (2001). The Palestinian Industrial Sector: Analysis of the Industrial Indications (from 1994 to 2000), Journal of the Palestinian Planning, The 1st Issue.

[17] Palestinian Central Bureau of Statistics, (2008). Population, Housing and Establishment Census (2007), The Economic Establishments, The Final Results, Ramallah-Palestine.

[18] Peter Hines and Nick Rich, (1997). The Seven Value Stream Mapping Tools, Published by International Journal of Operations and Production Management.

[19] Singh, R., (1999). Lean Manufacturing: Changing Paradigms in Product Manufacturing, the third International Conference on Quality Management, Delhi, India.

[20] Andreas Berg and Fredrik Ohlsson, (2005). Lean Manufacturing at Volvo Truck Production, Master Thesis, Lulea University of Technology. 
[21] Abdullah, F., (2003). Lean Manufacturing Tools and Techniques in the Process industry with a focus on Steel, $\mathrm{PhD}$ thesis, University of Pittsburgh.

[22] Jochen Czabke, (2007). Lean Thinking in the Secondary Wood Products Industry: Challenges and Benefits, Master Thesis, Oregon State University.

[23] Kazuhiro Yamashita, (2004). Implementation of Lean Manufacturing Process to XYZ Company in Minneapolis Area, Master Thesis, University of Wisconsin-Stout.

[24] Layla Badran, (2010). The Lean Manufacturing Philosophy for the Manufacturing and Service Organizations, Master thesis, Damascus University.

[25] M. Enaghani, M. Arashpour, and M. Karimi., (2009). The Relationship between Lean and TPM, Master Thesis, University of Boras.

[26] Moutasem Saleh, (2011). The Role of Thinking Capital in the Possibility of Establishing Lean Manufacturing Foundations, Master Thesis, University of Mosul.

[27] Naveen Rathi, (2009). A Framework for the Implementation of Lean Techniques in Process Industries, Master thesis, Texas Tech University.
[28] Philip Stephen, (2004). Application of DMAIC to integrate Lean Manufacturing and Six Sigma, Master thesis, The Virginia Polytechnic Institute and State University.

[29] Ramadane M. El-Kourd, (2009). A Study of Lean Construction in Gaza Strip, Master thesis, The Islamic University of Gaza.

[30] William McGrath, (2007). Impact Analysis of Large Scale Lean Manufacturing Initiatives Upon Manufacturing Process Innovation In Irish Companies, Master thesis, Waterford Institute of Technology.

[31] Contiuous Improvement Professionals, (2006). "Lean Manufacturing / Lean Production". http://www.dynamicbiz.us/366/article-leanmanufacturing.ht $\mathrm{ml}$.

[32] Ibrahim, M., (2011). "Lean Production Vs. Traditional Production".

[33] http://www.scribd.com/doc/49200950/lean-vs-traditional-ass ignment.

[34] Minggu, (2009). "A Brief History of Lean Manufacturing".

[35] http://accubekas.blogspot.com/2009_02_01_archive.html.

Means and Test Values for "Overproduction".

\begin{tabular}{|c|c|c|c|c|c|c|}
\hline No & Field & Mean & $\begin{array}{l}\text { Proportional } \\
\text { mean }(\%)\end{array}$ & $\begin{array}{l}\text { Test } \\
\text { value }\end{array}$ & $\begin{array}{l}\text { P-value } \\
\text { (Sig.) }\end{array}$ & Rank \\
\hline 1 & Minimizing overproduction in your company leads to preventing accumulation of units within the store & 4.26 & 85.11 & 8.69 & $0.000 *$ & 1 \\
\hline 2 & Minimizing overproduction in your company leads to reducing defects in your products. & 4.01 & 80.21 & 7.34 & $0.000 *$ & 5 \\
\hline 3 & Minimizing overproduction in your company allows more space within the work that can be exploited & 4.17 & 83.40 & 8.21 & $0.000 *$ & 2 \\
\hline 4 & Minimizing overproduction in your company reduces the staff and machines waiting in the other units. & 4.08 & 81.68 & 8.18 & $0.000^{*}$ & 4 \\
\hline 5 & $\begin{array}{l}\text { Minimizing overproduction in your company leads to better exploiting of the available human and } \\
\text { material resources. }\end{array}$ & $\mathrm{d}_{4.15}$ & 82.98 & 8.62 & $0.000 *$ & 3 \\
\hline 6 & $\begin{array}{l}\text { By the nature of your work, minimizing overproduction in your company reduces transport of materials } \\
\text { between work stations and machines. }\end{array}$ & $\mathrm{s}_{3.92}$ & 78.49 & 7.62 & $0.000^{*}$ & 7 \\
\hline 7 & $\begin{array}{l}\text { According to your experience, minimizing overproduction in your company reduces the need for } \\
\text { re-manufacturing of the product. }\end{array}$ & r 3.99 & 79.78 & 7.29 & $0.000 *$ & 6 \\
\hline 8 & All paragraphs of the field " Overproduction" & 4.09 & 81.79 & 8.96 & $0.000 *$ & \\
\hline
\end{tabular}

* The mean is significantly different from 3.

Means and Test Values for "Inventory".

\begin{tabular}{|c|c|c|c|c|c|c|}
\hline No & Field & Mean & $\begin{array}{l}\text { Proportional } \\
\text { mean }(\%)\end{array}$ & $\begin{array}{l}\text { Test } \\
\text { value } \\
\end{array}$ & $\begin{array}{l}\text { P-value } \\
\text { (Sig.) }\end{array}$ & Rank \\
\hline 1 & $\begin{array}{l}\text { Excess inventory minimization balances the flow of materials through the stages of production so as to } \\
\text { ensure there is no idle capacity. }\end{array}$ & $\mathrm{o}_{4.00}$ & 80.00 & 7.72 & $0.000 *$ & 3 \\
\hline 2 & When you minimize the excess inventory through working, your production defective units are less. & 3.91 & 78.30 & 7.29 & $0.000 *$ & 6 \\
\hline 3 & $\begin{array}{l}\text { Policy of minimizing the excess inventory leads to lower following-up and conditioning costs of pro- } \\
\text { duction units. }\end{array}$ & 4.12 & 82.34 & 7.81 & $0.000 *$ & 1 \\
\hline 4 & $\begin{array}{l}\text { When you minimize the excess inventory through working, you are better exploiting areas of the } \\
\text { workplace. }\end{array}$ & $\mathrm{e}_{3.93}$ & 78.51 & 7.04 & $0.000 *$ & 5 \\
\hline 5 & Excess inventory minimization reduces the number of workers needed in your production. & 4.02 & 80.43 & 7.16 & $0.000 *$ & 2 \\
\hline 6 & $\begin{array}{l}\text { By the nature of your work, excess inventory minimization reduces the materials transport between } \\
\text { work stations and machines }\end{array}$ & 3.91 & 78.30 & 6.75 & $0.000 *$ & 6 \\
\hline 7 & $\begin{array}{l}\text { According to your experience in your work, excess inventory minimization reduces the } \\
\text { re-manufacturing of the product. }\end{array}$ & $e_{3.96}$ & 79.14 & 7.07 & $0.000 *$ & 4 \\
\hline 8 & $\begin{array}{l}\text { All paragraphs of the field } \\
\text { " Inventory" }\end{array}$ & 3.98 & 79.57 & 8.30 & $0.000 *$ & \\
\hline
\end{tabular}

* The mean is significantly different from 3. 


\begin{tabular}{|c|c|c|c|c|c|c|}
\hline No & Field & Mean & $\begin{array}{l}\text { Proportional } \\
\text { mean }(\%)\end{array}$ & $\begin{array}{l}\text { Test } \\
\text { value }\end{array}$ & $\begin{array}{l}\text { P-value } \\
\text { (Sig.) }\end{array}$ & Rank \\
\hline 1 & Over-processing minimization leads to a better use of time and efforts. & 4.03 & 80.64 & 7.68 & $0.000 *$ & 4 \\
\hline 2 & $\begin{array}{l}\text { Over-processing minimization helps in reducing the movement barriers of people and materials during } \\
\text { the work. }\end{array}$ & $\mathrm{g}_{4.04}$ & 80.85 & 7.94 & $0.000^{*}$ & 3 \\
\hline 3 & $\begin{array}{l}\text { Over-processing minimization balances the flow of materials through the stages of production so as to } \\
\text { ensure there is no idle capacity. }\end{array}$ & 0.01 & 80.21 & 7.94 & $0.000^{*}$ & 6 \\
\hline 4 & Over-processing minimization in your company can reduce the workers useless movements. & 4.15 & 82.95 & 7.75 & $0.000^{*}$ & 2 \\
\hline 5 & Over-processing minimization reduces the materials used in your product line. & 4.18 & 83.64 & 7.84 & $0.000 *$ & 1 \\
\hline 6 & $\begin{array}{l}\text { By the nature of your work, over-processing minimization reduces the materials transport between } \\
\text { work stations and machines. }\end{array}$ & 4.02 & 80.42 & 7.59 & $0.000^{*}$ & 5 \\
\hline \multirow[t]{2}{*}{7} & According to your experience in your work, over-processing minimization reduces the workers stress. & 3.96 & 79.15 & 7.50 & $0.000^{*}$ & 7 \\
\hline & $\begin{array}{l}\text { All paragraphs of the field } \\
\text { " Over-processing" }\end{array}$ & 4.02 & 80.33 & 8.44 & $0.000^{*}$ & \\
\hline
\end{tabular}

* The mean is significantly different from 3.

Means and Test Values for "Motion".

\begin{tabular}{|c|c|c|c|c|c|c|}
\hline No & Field & Mean & $\begin{array}{l}\text { Proportional } \\
\text { mean }(\%)\end{array}$ & $\begin{array}{l}\text { Test } \\
\text { value }\end{array}$ & $\begin{array}{l}\text { P-value } \\
\text { (Sig.) }\end{array}$ & Rank \\
\hline $1-$ & Workers motion minimization facilitates the task of management in controlling the work. & 4.13 & 82.53 & 8.09 & $0.000^{*}$ & 5 \\
\hline $2-$ & $\begin{array}{l}\text { Workers motion minimization in your company reduces the waiting machines and leads to greater } \\
\text { exploitation of the potential. }\end{array}$ & $\mathrm{r}_{4.16}$ & 83.26 & 8.73 & $0.000^{*}$ & 4 \\
\hline $3-$ & Workers motion minimization reduces the injuries at work. & 4.18 & 83.66 & 8.46 & $0.000^{*}$ & 3 \\
\hline 4- & Workers motion minimization in your company reduces the energy wasted. & 4.24 & 84.83 & 8.55 & $0.000^{*}$ & 1 \\
\hline 5- & Workers motion minimization leads to better exploiting of the areas. & 4.22 & 84.49 & 8.33 & $0.000^{*}$ & 2 \\
\hline 6- & By the nature of your work, workers motion minimization reduces the production of defective units. & 4.08 & 81.57 & 8.04 & $0.000^{*}$ & 7 \\
\hline \multirow[t]{2}{*}{ 7- } & $\begin{array}{l}\text { According to your experience in your work, workers motion minimization reduces the } \\
\text { re-manufacturing of the product. }\end{array}$ & $e_{4.11}$ & 82.27 & 7.75 & $0.000^{*}$ & 6 \\
\hline & All paragraphs of the field " Motion" & 4.15 & 83.01 & 9.02 & $0.000^{*}$ & \\
\hline
\end{tabular}

* The mean is significantly different from 3.

Means and Test Values for "Waiting".

\begin{tabular}{|c|c|c|c|c|c|c|}
\hline No & Field & Mean & $\begin{array}{l}\text { Proportional } \\
\text { mean(\%) }\end{array}$ & $\begin{array}{l}\text { Test } \\
\text { value }\end{array}$ & $\begin{array}{l}\text { P-value } \\
\text { (Sig.) }\end{array}$ & Rank \\
\hline $1-$ & Workers and machines waiting minimization help in greater exploitation of the potential of working. & .4 .16 & 83.23 & 8.24 & $0.000^{*}$ & 2 \\
\hline 2- & Workers and machines waiting minimization during your production reduce the work injury. & 4.10 & 81.91 & 8.03 & $0.000 *$ & 4 \\
\hline 3- & $\begin{array}{l}\text { Workers and machines waiting minimization improve the skills of communication between depart- } \\
\text { ments, and thus reduce errors during the production process. }\end{array}$ & 4.06 & 81.29 & 8.34 & $0.000 *$ & 6 \\
\hline 4- & $\begin{array}{l}\text { Workers and machines waiting minimization facilitate the task of management in the control of hu- } \\
\text { man resources. }\end{array}$ & - 4.14 & 82.77 & 8.67 & $0.000 *$ & 3 \\
\hline 5- & Workers and machines waiting minimization facilitate the monitoring of product quality. & 4.18 & 83.62 & 8.60 & $0.000 *$ & 1 \\
\hline 6- & $\begin{array}{l}\text { By the nature of your work, workers and machines waiting minimization reduces the materials } \\
\text { transport between work stations and machines. }\end{array}$ & $\mathrm{s}_{4.08}$ & 81.51 & 8.06 & $0.000 *$ & 5 \\
\hline \multirow[t]{2}{*}{ 7- } & $\begin{array}{l}\text { According to your experience, workers and machines waiting minimization reduces the product } \\
\text { re-manufacturing. }\end{array}$ & 4.03 & 80.64 & 7.81 & $0.000 *$ & 7 \\
\hline & All paragraphs of the field "Waiting" & 4.11 & 82.10 & 8.86 & $0.000^{*}$ & \\
\hline
\end{tabular}

* The mean is significantly different from 3.

Means and Test Values for "Defects".

\begin{tabular}{|c|c|c|c|c|c|c|}
\hline No & Field & Mean & $\begin{array}{l}\text { Proportional } \\
\text { mean(\%) }\end{array}$ & $\begin{array}{l}\text { Test } \\
\text { value }\end{array}$ & $\begin{array}{l}\text { P-value } \\
\text { (Sig.) }\end{array}$ & Rank \\
\hline $1-$ & $\begin{array}{l}\text { Defects minimization leads to better reputation with customers and increasing the marketing of the } \\
\text { product. }\end{array}$ & 4.57 & 91.40 & 9.17 & $0.000 *$ & 1 \\
\hline $2-$ & $\begin{array}{l}\text { Defects minimization reduces the bottlenecks that impede the movement of workers and materials } \\
\text { during the work. }\end{array}$ & $\mathrm{ls}_{4.29}$ & 85.87 & 8.95 & $0.000 *$ & 2 \\
\hline $3-$ & Defects minimization reduces re-manufacturing the same products. & 4.09 & 81.74 & 8.10 & $0.000 *$ & 5 \\
\hline
\end{tabular}




\begin{tabular}{|c|c|c|c|c|c|}
\hline 4- & Defects minimization reduces the excess movement of workers. & 82.34 & 8.22 & $0.000 *$ & 3 \\
\hline $5-$ & Defects minimization leads to the optimal use materials and human resources. & 81.14 & 6.98 & $0.000 *$ & 6 \\
\hline $6-$ & $\begin{array}{l}\text { By the nature of your work, defects minimization reduces the materials transport between work sta- } \\
\text { tions and machines. }\end{array}$ & 80.65 & 7.59 & $0.000 *$ & 7 \\
\hline \multirow[t]{2}{*}{ 7- } & $\begin{array}{l}\text { According to your experience in your work, defects minimization reduces the re-manufacturing of } 4.11 \\
\text { the product. }\end{array}$ & 82.15 & 7.81 & $0.000 *$ & 4 \\
\hline & All paragraphs of the filed " Defects" & 83.56 & 8.97 & $0.000 *$ & \\
\hline
\end{tabular}

* The mean is significantly different from 3.

Means and Test Values for "Transportation".

\begin{tabular}{|c|c|c|c|c|c|c|}
\hline No & Field & Mean & $\begin{array}{l}\text { Proportional } \\
\text { mean } \\
(\%) \\
\end{array}$ & $\begin{array}{l}\text { Test } \\
\text { value }\end{array}$ & $\begin{array}{l}\text { P-value } \\
\text { (Sig.) }\end{array}$ & Rank \\
\hline $1-$ & $\begin{array}{l}\text { Materials and products transportation minimization reduces the necessary energy, such as, number } \\
\text { of workers and electricity. }\end{array}$ & $\mathrm{r}_{4.16}$ & 83.19 & 8.36 & $0.000 *$ & 3 \\
\hline $2-$ & $\begin{array}{l}\text { Materials and products transportation minimization reduces the bottlenecks that impede the } \\
\text { movement of people and materials during the work. }\end{array}$ & e 3.99 & 79.79 & 7.13 & $0.000 *$ & 7 \\
\hline $3-$ & $\begin{array}{l}\text { Materials and products transportation minimization in your company reduces the risk of damaged } \\
\text { units or defects. }\end{array}$ & $\mathrm{d}_{4.03}$ & 80.64 & 7.78 & $0.000 *$ & 6 \\
\hline 4- & Materials and products transportation minimization reduces the waiting workers and machines. & 4.11 & 82.15 & 8.33 & $0.000 *$ & 4 \\
\hline $5-$ & Materials and products transportation minimization leads to better exploiting of the areas. & 4.17 & 83.44 & 8.62 & $0.000 *$ & 1 \\
\hline $6-$ & $\begin{array}{l}\text { By the nature of your work, materials and products transportation minimization facilitates the } \\
\text { control of materials and human resources. }\end{array}$ & $e_{4.17}$ & 83.40 & 8.21 & $0.000^{*}$ & 2 \\
\hline \multirow[t]{2}{*}{ 7- } & $\begin{array}{l}\text { According to your experience in your work, materials and products transportation minimization } \\
\text { reduces the re-manufacturing of the product. }\end{array}$ & $\mathrm{n}_{4.11}$ & 82.11 & 7.44 & $0.000 *$ & 5 \\
\hline & All paragraphs of the filed " Transportation" & 4.10 & 81.94 & 8.50 & $0.000 *$ & \\
\hline
\end{tabular}

* The mean is significantly different from 3. 